\title{
PENGARUH PEMBERIAN PUDING SUSU BUAH NAGA MERAH (Hylocereus polyrhizus) TERHADAP KADAR GLUKOSA DARAH PUASA PASIEN DIABETES MELLITUS TIPE 2
}

\author{
Nunung Setyani ${ }^{1}$, Ni Ketut Sri Sulendri ${ }^{2}$, Fifi Luthfiyah ${ }^{2}$, Suhaema $^{2}$ \\ ${ }^{1}$ Mahasiswa Jurusan Gizi, Poltekkes Kemenkes Mataram \\ ${ }^{2}$ Dosen Jurusan Gizi, Poltekkes Kemenkes Mataram \\ J1. Praburangkasari Dasan Cermen, Sandubaya Kota Mataram \\ Telp./Fax. (0370) 633837 \\ Email : jurnalgiziprima1@gmail.com \\ Kurnia Aprilia Abdila, Poltekkes Kemenkes Mataram \\ Email : nununganama@gmail.com
}

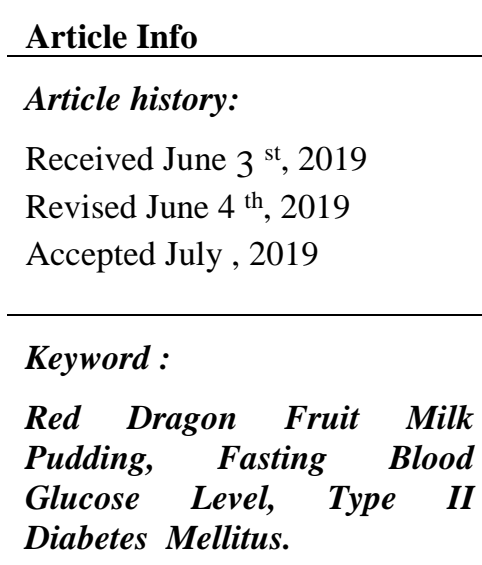

\begin{abstract}
Background: One of the typical signs of diabetes mellitus (DM) is hyperglycemia, which is one medical condition that consists of increasing hormone levels within normal limits. Basic Health Research Results in 2018 DM prevalence in Indonesia increased from 6.9\% in 2013 to 8.5\% in 2018 (Ministry of Health, 2018). One of the nutritional therapies for the management of diabetes mellitus is fiber consumption. Fruit which contains high fiber, one of which is dragon fruit. Research by Wiardani et al., (2014) provides dragon fruit juice 200 grams of blood glucose levels in DM patients with an average decrease in Prondrial 2 hours Post blood calcium level (2JPP) of $79.1 \mathrm{mg} / \mathrm{dL}$ and research by Hidayati (2017) ) by giving red dragon fruit 200 grams of reduction in fasting blood by $19.1 \mathrm{mg} /$ dL.Purpose :To determine the difference in levels of red dragon fruit (hylocereus polyrhizus) against decreasing fasting blood glucose levels of type 2 diabetes patien Method: Research quasy experimental pre post test with control group. Results: The results of the statistical analysis paired with the t-test in the assessment group showed differences in the fasting blood levels of the pretest-posttest with a $p$ value of 0.008 ( $p<0.05)$, meaning that it was consistent with contributions related to blood count before and replacement. The results of the independent $t$-test showed that there was no difference in the difference between fasting blood levels in the advisory group and the control group that discussed the $p$ value of 0.070. ( $p$ > 0.05).Conclusion: There is no contribution of giving red dragon fruit milk pudding (Hylocereus polyrhizus) to the reduction of blood glucose levels of type II diabetes mellitus patients.
\end{abstract}

\section{ABSTRAK}

Latar Belakang : Salah satu tanda khas penyakit diabetes mellitus (DM) adalah adanya hiperglikemia, yaitu suatu kondisi medik berupa peningkatan kadar glukosa dalam darah melebihi batas normal. Hasil Riset Kesehatan Dasar tahun 2018 prevalensi DM di Indonesia mengalami peningkatan dari $6,9 \%$ pada tahun 2013 menjadi $8,5 \%$ pada tahun 2018 (Kemenkes, 2018). Salah satu terapi gizi medis penatalaksanaan diabetes mellitus adalah konsumsi serat. Buah yang megandung tinggi serat salah satunya buah naga. Penelitian oleh Wiardani et al., (2014) pemberian jus buah naga 200 gram 
menurunkan kadar glukosa darah pasien DM dengan rata-rata penurunan kadar glukosa darah 2 Jam Post Prondrial (2JPP) sebesar $79,1 \mathrm{mg} / \mathrm{dL}$ dan penelitian oleh Hidayati (2017) dengan pemberian buah naga merah 200 gram menurunkan glukosa darah puasa sebesar 19,1 mg/dL.Tujuan : Untuk mengetahui pengaruh puding susu buah naga merah (hylocereus polyrhizus) terhadap penurunan kadar gukosa darah puasa (GDP) pasien diabetes tipe 2 Metode : Penelitian Quasy eksperimental dengan pre post test with control group. _Hasil penelitian :Hasil analisis statistik paired t-test pada kelompok perlakuan menunjukkan adanya perbedaan kadar glukosa darah puasa pretest-posttest dengan nilai $p$ value $0.008(\mathrm{p}<0.05)$, berarti terdapat perbedaan yang bermakna antara kadar glukosa darah sebelum dan sesudah intervensi. Hasil uji independent t-test menunjukkan tidak adanya perbedaan selisih kadar glukosa darah puasa pada kelompok perlakuan dan kelompok kontrol yang ditunjukkan dengan nilai $p$ value sebesar 0,070. ( $>00.05)$.Kesimpulan: Tidak Ada pengaruh pemberian puding susu buah naga merah (Hylocereus polyrhizus) terhadap penurunan kadar glukosa darah puasa pasien diabetes melitus tipe II. 


\section{PENDAHULUAN}

Salah satu tanda khas penyakit diabetes mellitus (DM) adalah adanya hiperglikemia, yaitu suatu kondisi medik berupa peningkatan kadar glukosa dalam darah melebihi batas normal. Saat ini penelitian epidemiologi menunjukkan adanya kecenderungan peningkatan angka insidensi dan prevalensi DM tipe-2 di berbagai penjuru dunia. Menurut World Health Organization (WHO) memprediksi kenaikan jumlah penyandang DM di Indonesia dari 8,4 juta pada tahun 2000 menjadi sekitar 21,3 juta pada tahun 2030. Hal ini menunjukkan adanya peningkatan jumlah penyandang DM sebanyak 2-3 kali lipat pada tahun 2035. Sedangkan International Diabetes Federation (IDF) memprediksi adanya kenaikan jumlah penyandang DM di Indonesia dari 9,1 juta pada tahun 2014 menjadi 14,1 juta pada tahun 2035 (Perkeni, 2015).

Berdasarkan hasil Riset Kesehatan Dasar tahun 2018 prevalensi DM di Indonesia mengalami peningkatan dari 6,9\% pada tahun 2013 menjadi 8,5\% pada tahun 2018 (Riskesdas, 2018). Dari hasil Buku Pencatatan Posbindu Penyakit Tidak Menular di 10 posbindu wilayah kerja Puskesmas Babakan diperoleh data bahwa Kelurahan Abian Tubuh Baru tertinggi penderita diabetes mellitus dengan pravelensi 12,9\%. Diabetes sendiri merupakan penyakit kronis yang akan dialami seumur hidup sehingga progresifitas penyakit akan terus berjalan dan menimbulkan komplikasi diantaranya komplikasi pada pembulu darah, gangguan fungsi organ (ginjal, mata, sistem saraf), serta tidak stabilnya tekanan darah (Mahendra et al., 2008).

Terdapat empat pilar penatalaksanaan DM yaitu edukasi, Terapi Gizi Medis (TGM), aktifitas fisik, dan terapi farmakologis. Salah satu anjuran dalam terapi gizi medis adalah mengkonsumsi serat dalam jumlah yang cukup. Konsumsi serat penderita diabetes mellitus masih rendah, berdasarkan penelitian oleh Wiardani et al., (2007) dan Rahmawati (2010) rerata konsumsi serat pasien diabetes mellitus masih <10 gram/hari sementara anjuran konsumsi serat menurut Perkeni (2015) sebesar 20-35 gram/hari, sehingga dibutuhkan makanan tinggi serat untuk menunjang kebutuhan serat yang belum tercukupi.Mekanisme serat pangan dalam menurunkan kadar gula darah pasien diabetes adalah dengan menurunkan efisiensi penyerapan karbohidrat sehingga menyebabkan turunnya respon insulin. Menurunnya respon insulin ini mengakibatkan kerja pankreas semakin ringan sehingga dapat memperbaiki fungsi pankreas dalam menghasilkan insulin (Astawan and Kasih, 2008).

Penelitian terkait hubungan konsumsi serat dengan Diabetes Mellitus tipe 2 diantaranya adalah penelitian yang dilakukan oleh Rahmawati (2010) di RSUD Kalisat Kabupaten Jember dengan rerata asupan serat 9,1 g/hari. Penelitian lain oleh Bintanah dan Handarsari (2012) di Rumah Sakit Roemani Semarang dengan rerata asupan serat 7,98 g/hari. Dari penelitian tersebut didapatkan hubungan antara asupan serat dengan kadar glukosa darah. Serat mempunyai kemampuan untuk memperlambat penyerapan glukosa dan lemak dengan cara meningkatkan kekentalan feses yang secara tidak langsung menurunkan kecepatan difusi sehingga kadar glukosa darah, profil lipid dan kolesterol menurun (Sulistyani, 2012 dalam Hidayati, 2017).

Salah satu buah yang mengandung serat tinggi adalah buah naga merah. Setiap 100 gram buah naga merah terkandung 3,2 gram serat (Mahmud et al., 2017). Berbagai penelitian menunjukan buah naga mampu menurunkan kadar glukosa darah diantaranya penelitian yang dilakukan oleh Wiardani et al., (2014) pemberian jus buah naga 200 gram dalam $250 \mathrm{ml}$ paling efektif menurunkan kadar glukosa darah pasien DM dibandingkan 100 gram buah naga dalam $250 \mathrm{ml}$ dengan rata-rata penurunan kadar glukosa darah 2 Jam Post Prondrial (2 JPP) sebesar 79,1 $\mathrm{mg} / \mathrm{dL}$. Selain itu penelitian oleh Hidayati (2017) menunjukan adanya pengaruh pemberian buah naga merah 200 gram terhadap kadar glukosa darah puasa pasien diabetes mellitus tipe 2 sebesar 19,1 mg/dL di Puskesmas Temon 1 Kulon Progo Yogyakarta. Selain kandungan serat buah naga juga mengandung senyawa likopen yaitu pigmen pemberi warna merah pada buah naga. Likopen mempengaruhi resistensi hormon insulin sehingga toleransi tubuh terhadap glukosa meningkat (Astawan and Kasih, 2008).

Salah satu bentuk olahan buah naga adalah puding. Puding adalah sejenis makanan terbuat dari pati dapat berupa agar-agar tepung-tepungan atau hasil olahannya (Faridah et al., 2008). Pengolahan buah naga yang dimasak bersama agar-agar untuk penderita diabetes oleh Firdayati (2015) menunjukan tidak adanya pengaruh yang bermakna pada pemberian agar-agar buah naga merah (Hylocereus polyrhizus) dalam penurunan kadar glukosa darah puasa penderita Diabetes Mellitus tipe II di wilayah kerja Puskesmas Salido. Hal ini dikarenakan proses pemanasan pada buah naga akan menyebabkan penurunan pada kandungan serat dan antioksidan (Puspaningtyas, 2013 dalam Firdayati, 2015).

Puding yang akan diberikan untuk pasien diabetes perlu mempertimbangkan jumlah, jenis dan jadwal. Puding sebagai makanan selingan untuk penyandang diabetes harus mengandung 10-15\% dari total energi (Almatsier, 2004). Rerata kebutuhan energi pasien diabetes yaitu $2000 \mathrm{kkal}$, sehingga rentang porsi selingan untuk pasien 
diabetes adalah $200 \mathrm{kkal}$ - $300 \mathrm{kkal}$. Dalam 200 g buah naga hanya mengandung $142 \mathrm{kkal}$, sehingga untuk memenuhi persentase anjuran konsumsi selingan perlu ditambahkan bahan makanan lain. Berdasarkan permasalahan tersebut peneliti tertarik membuat puding dengan tambahan susu skim untuk meningkatkan nilai energi sehingga menjadi puding susu buah naga. Menurut Martini dan Wood (2009) konsumsi susu rendah lemak dapat menjadi bagian dari diet yang sehat. Selain itu penelitian oleh Liu et al., (2006) konsumsi susu rendah lemak menurunkan resiko diabetes tipe 2 pada wanita. Pembuatan puding susu buah naga berbahan dasar buah naga, susu skim dan jeli sehingga

\begin{tabular}{lllll} 
Karakteristik & Perlakuan & Kontrol & Total & $p$ \\
\hline
\end{tabular}

menjadi alternatif makanan selingan yang sehat bagi penderita diabetes.

\section{METODE}

Penelitian ini dilakukan di kelurahan Abian Tubuh Baru Wilayah Kerja Puskesmas Babakan pada bulan Desember 2018 sampai dengan Juni 2019. Jenis penelitian yaitu quasy eksperiment dengan pre-post test with control group. Media yang digunakan adalah uang logam. Pada penelitian ini kadar glukosa darah sebagai variabel terikat sedangkan variabel bebasnya adalah asupan puding susu buah naga merah.

Responden dalam penelitian ini adalah pasien yang terdiagnosis diabetes sebanyak 20 responden yang didistribusikan dalam 2 kelompok yaitu 10 responden sebagai kelompok intervensi dan 10 responden lainnya sebagai kelompok kontrol. Pada kelompok intervensi pada penelitan ini diberikan puding susu buah naga merah. Dengan penggunaan buah naga merah seberat 200 gram selama 10 hari. Buah naga merah diperoleh dari pedagang kaki lima di jalan Air Langga, bahan lain pembuatan puding yaitu 4 g nutrijell, $30 \mathrm{~g}$ susu skim $1 \mathrm{~g}$ gula diabetes. Pengukuran kadar glukosa darah dilakukan pada hari ke 0 dan hari ke 11 pada kelompok kontrol maupun intervensi. Sebelum dilakukan pengukuran kadar glukosa darah puasa responden diminta untuk berpuasa minimal 8 jam.

Data yang dikumpulkan yaitu data primer (karakteristik sampel, asupan zat gizi, data kadar glukosa darah puasa sebelum dan sesudah penelitian serta perbedaan rerata kadar glukosa darah.) dan data sekunder (usia, alamat dan dignosa penyakit). Uji normalitas menggunakan uji Saphiro-wilk. Perbedaan kadar GDP sebelum dan sesudah penelitian pada kedua kelompok menggunakan uji paired t-test. Perbedaan pengaruh kadar GDP pada kedua kelompok di analisis dengan menggunakan uji mann-whitney.

\section{Hasil}

\section{Karakteristik Sampel Penelitian}

Karakteristik sampel yang dikumpulkan meliputi, umur, jenis kelamin, riwayat penyakit keluarga, status gizi, konsumsi obat-obatan antidiabetes, aktifitas fisik dan asupanan makanan. Sampel penelitian sebanyak 20 sampel yang terdiri dari 10 sampel perlakuan dan 10 sampel kontrol. Karakteristik sampel secara lengkap dapat dilihat pada tabel 1 . 


\begin{tabular}{|c|c|c|c|c|c|c|c|}
\hline & $\mathbf{n}$ & $\%$ & $\mathbf{n}$ & $\%$ & $\mathbf{n}$ & $\%$ & \\
\hline & & & & & & & \\
\hline 40-49 tahun & 2 & 20 & 1 & 10 & 3 & 15 & \multirow{4}{*}{0.023} \\
\hline $50-59$ tahun & 2 & 20 & 8 & 80 & 10 & 50 & \\
\hline $60-69$ tahun & 6 & 60 & 1 & 10 & 17 & 35 & \\
\hline Total & 10 & 100 & 10 & 100 & 20 & 100 & \\
\hline \multicolumn{8}{|c|}{ Jenis kelamin } \\
\hline Laki-laki & 6 & 60 & 1 & 10 & 7 & 35 & \multirow{3}{*}{0.019} \\
\hline Perempuan & 4 & 40 & 9 & 90 & 13 & 65 & \\
\hline Total & 10 & 10 & 10 & 100 & 20 & 100 & \\
\hline \multicolumn{8}{|c|}{ Riwayat penyakit keluarga } \\
\hline Ada & 6 & 60 & 6 & 60 & 12 & 60 & \multirow{3}{*}{1.000} \\
\hline Tidak Ada & 4 & 40 & 4 & 40 & 8 & 40 & \\
\hline Total & 10 & 100 & 10 & 100 & 20 & 100 & \\
\hline \multicolumn{8}{|c|}{ Konsumsi obat antidiabetes } \\
\hline $\mathrm{Ya}$ & 6 & 60 & 8 & 80 & 14 & 70 & \multirow{3}{*}{0.329} \\
\hline Tidak & 4 & 40 & 2 & 20 & 6 & 30 & \\
\hline Total & 10 & 100 & 10 & 100 & 20 & 100 & \\
\hline \multicolumn{8}{|c|}{ Aktifitas fisik } \\
\hline Keadaan istirahat & 3 & 30 & 0 & 0 & 3 & 15 & \multirow{4}{*}{0.079} \\
\hline Aktifitas ringan & 7 & 70 & 8 & 80 & 15 & 75 & \\
\hline Aktifitas sedang & 0 & 0 & 2 & 20 & 2 & 10 & \\
\hline Total & 10 & 100 & 10 & 100 & 20 & 100 & \\
\hline \multicolumn{8}{|c|}{ Status Gizi menurut IMT } \\
\hline Berat badan kurang & 1 & 10 & 1 & 10 & 2 & 10 & \multirow{6}{*}{0.970} \\
\hline Berat badan normal & 2 & 20 & 3 & 30 & 5 & 25 & \\
\hline Beresiko & 2 & 20 & 2 & 20 & 4 & 20 & \\
\hline Obes I & 3 & 30 & 3 & 30 & 6 & 30 & \\
\hline Obes II & 2 & 20 & 1 & 10 & 3 & 15 & \\
\hline Total & 10 & 100 & 10 & 100 & 20 & 100 & \\
\hline \multicolumn{8}{|c|}{ Status Gizi menurut Lingkar Pinggang } \\
\hline Obesitas & 6 & 60 & 8 & 80 & 14 & 70 & \multirow{3}{*}{0.329} \\
\hline Normal & 4 & 40 & 2 & 20 & 6 & 30 & \\
\hline Total & 10 & 100 & 10 & 100 & 20 & 100 & \\
\hline
\end{tabular}

Tabel 1. Karakteristik Sampel Penelitian

Berdasarkan Karakteristik sampel menunjukkan sebagian besar (50\%) sampel berumur 50-59 tahun. Dilihat dari jenis kelamin menunjukkan sebagian besar (65\%) berjenis kelamin perempuan, dengan $60 \%$ sampel memiliki riwayat keluarga menderita diabetes dan sebanyak $70 \%$ sampel mengkonsumsi obat antidiabetes. Berdasarkan aktifitas fisik sebagian besar $(75 \%)$ responden termasuk kategori aktifitas ringan dan status gizi menurut IMT sebanyak 65\% termasuk kategori obesitas sedangkan status gizi berdasarkan lingkar pinggang 70\% termasuk kategori obesitas sentral.

\section{Asupan zat gizi}

Tingkat konsumsi untuk penelitian ini menggunakan metode food recall 24 jam yang dilakukan sebanyak 2 kali yaitu 1 kali sebelum penelitian dan 1 kali selama penelitian. Tingkat konsumsi selama penelitian termasuk konsumsi puding susu buah naga merah (Hylocereus polyrhizus) yang diberikan selama 10 hari pada sampel perlakuan dengan berat puding 300 gram. Dilihat dari konsumsi puding susu buah naga yang diberikan diketahui seluruh (tingkat konsumsi 100\%) sampel perlakuan mampu menghabiskannya. Asupan zat gizi secara lengkap dapat dilihat pada tabel 2. 
Tabel 2. Karakteristik Tingkat Konsumsi

\begin{tabular}{|c|c|c|c|c|c|c|c|c|c|c|}
\hline \multirow[b]{3}{*}{ Zat Gizi } & \multicolumn{5}{|c|}{ Tingkat konsumsi sebelum } & \multicolumn{5}{|c|}{ Tingkat konsumsi selama } \\
\hline & \multicolumn{2}{|c|}{ Perlakuan } & \multicolumn{2}{|c|}{ Kontrol } & \multirow[b]{2}{*}{$p$} & \multicolumn{2}{|c|}{ Perlakuan } & \multicolumn{2}{|c|}{ kontrol } & \multirow[b]{2}{*}{$p$} \\
\hline & $\mathrm{n}$ & $\%$ & $\mathrm{n}$ & $\%$ & & $\mathrm{n}$ & $\%$ & $\mathrm{n}$ & $\%$ & \\
\hline \multicolumn{11}{|l|}{ Energi } \\
\hline lebih & 0 & 0 & 0 & 0 & & 2 & 20 & 0 & 0 & \\
\hline baik & 7 & 70 & 4 & 40 & & 6 & 60 & 5 & 50 & \\
\hline kurang & 3 & 30 & 6 & 60 & & 2 & 20 & 5 & 50 & \\
\hline Total & 10 & 100 & 10 & 100 & 0.178 & 10 & 100 & 10 & 100 & 0.185 \\
\hline \multicolumn{11}{|l|}{ Protein } \\
\hline lebih & 5 & 50 & 2 & 20 & & 8 & 80 & 0 & 0 & \\
\hline baik & 3 & 30 & 1 & 10 & & 2 & 20 & 2 & 20 & \\
\hline kurang & 2 & 20 & 7 & 70 & & 0 & 0 & 8 & 80 & \\
\hline Total & 10 & 100 & 10 & 100 & 0.080 & 10 & 100 & 10 & 100 & 0.000 \\
\hline \multicolumn{11}{|l|}{ Lemak } \\
\hline lebih & 7 & 70 & 5 & 50 & & 7 & 70 & 4 & 40 & \\
\hline baik & 1 & 10 & 2 & 20 & & 2 & 20 & 2 & 20 & \\
\hline kurang & 2 & 20 & 3 & 30 & & 1 & 10 & 4 & 40 & \\
\hline Total & 10 & 100 & 10 & 100 & 0.648 & 10 & 100 & 10 & 100 & 0.270 \\
\hline \multicolumn{11}{|c|}{ Karbohidrat } \\
\hline lebih & 0 & 0 & 0 & 0 & & 1 & 10 & 0 & 0 & \\
\hline baik & 3 & 30 & 0 & 0 & & 3 & 30 & 0 & 0 & \\
\hline kurang & 7 & 70 & 10 & 100 & & 6 & 60 & 10 & 100 & \\
\hline Total & 10 & 100 & 10 & 100 & 0.060 & 10 & 100 & 10 & 100 & 0.820 \\
\hline \multicolumn{11}{|l|}{ Serat } \\
\hline kurang & 10 & 100 & 10 & 100 & & 10 & 100 & 10 & 100 & \\
\hline Total & 10 & 100 & 10 & 100 & & 10 & 100 & 10 & 100 & \\
\hline
\end{tabular}

Tabel 3. Rerata Persentase Asupan

\begin{tabular}{|c|c|c|c|}
\hline variabel & $\begin{array}{c}\text { Perlakuan }(n=10) \\
\text { Mean } \pm \text { SD }\end{array}$ & $\begin{array}{c}\text { Kontrol }(\mathrm{n}=10) \\
\text { Mean } \pm \text { SD }\end{array}$ & $p$ \\
\hline $\begin{array}{l}\text { ENERGI } \\
\text { asupan energi sebelum(\%) } \\
\text { asupan energi selama }(\%)\end{array}$ & $\begin{array}{c}96.7 \pm 16.8 \\
106.3 \pm 21.05 \\
\end{array}$ & $\begin{array}{c}81.9 \pm 27.4 \\
80.27 \pm 40.2 \\
\end{array}$ & $\begin{array}{l}0.161 \\
0.005 \\
\end{array}$ \\
\hline $\begin{array}{l}\text { PROTEIN } \\
\text { asupan protein sebelum }(\%) \\
\text { asupan protein selama }(\%)\end{array}$ & $\begin{array}{l}130.7 \pm 58.9 \\
170.8 \pm 46.3 \\
\end{array}$ & $\begin{array}{c}80.27 \pm 40.28 \\
72.3 \pm 23.06 \\
\end{array}$ & $\begin{array}{l}0.038 \\
0.000 \\
\end{array}$ \\
\hline $\begin{array}{l}\text { LEMAK } \\
\text { asupan lemak sebelum(\%) } \\
\text { asupan lemak selama }(\%)\end{array}$ & $\begin{array}{c}143.4 \pm 58.01 \\
153.2 \pm 48.6\end{array}$ & $\begin{array}{l}125.6 \pm 66.02 \\
113.02 \pm 44.9\end{array}$ & $\begin{array}{l}0.530 \\
0.071 \\
\end{array}$ \\
\hline $\begin{array}{l}\text { KARBOHIDRAT } \\
\text { asupan karbohidrat sebelum }(\%) \\
\text { asupan karbohidrat selama }(\%)\end{array}$ & $\begin{array}{l}86.5 \pm 13.5 \\
89.2 \pm 21.7 \\
\end{array}$ & $\begin{array}{c}69.4 \pm 16.6 \\
73.5 \pm 8.7 \\
\end{array}$ & $\begin{array}{l}0.022 \\
0.049 \\
\end{array}$ \\
\hline $\begin{array}{l}\text { SERAT } \\
\text { asupan serat sebelum }(\%) \\
\text { asupan serat selama }(\%)\end{array}$ & $\begin{array}{c}38.9 \pm 18.5 \\
57.6 \pm 12.62\end{array}$ & $\begin{array}{l}27.4 \pm 11.2 \\
33.0 \pm 17.4\end{array}$ & $\begin{array}{l}0.112 \\
0.002\end{array}$ \\
\hline
\end{tabular}

Berdasarkan tabel 2 dan 3 dapat dilihat tingkat konsumsi energi sampel perlakuan sebelum penelitian sebanyak $70 \%$ termasuk kategori baik dengan rerata persentase asupan $96.7 \% \pm 16.8 \%$ dan selama penelitian sebanyak $60 \%$ termasuk kategori baik dengan rerata persentase asupan $106.3 \% \pm 21.05 \%$. Pada sampel kontrol tingkat konsumsi energi sebelum penelitian sebanyak $60 \%$ termasuk kategori kurang dengan rerata persentase asupan energi $81.9 \% \pm 27.4 \%$ dan selama penelitian sebanyak $50 \%$ termasuk kategori kurang dengan rerata persentase asupan $80.27 \pm 40.2 \%$. Sedangkan tingkat konsumsi protein sampel perlakuan sebelum penelitian sebanyak $50 \%$ termasuk kategori lebih dengan rerata persentase asupan $130.7 \% \pm 58.9 \%$ dan selama penelitian sebanyak $80 \%$ termasuk 
kategori lebih dengan rerata persentase asupan $153.2 \% \pm 48.6 \%$. Pada sampel kontrol tingkat konsumsi protein sebelum penelitian sebanyak $70 \%$ termasuk kategori kurang dengan rerata persentase asupan protein $80.27 \% \pm 40.28 \%$ dan selama penelitian sebanyak $80 \%$ termasuk kategori kurang dengan rerata persentase asupan protein $72.3 \% \pm 23.06 \%$.

Tingkat konsumsi lemak sampel perlakuan sebelum dan selama penelitian sebanyak $70 \%$ termasuk kategori lebih dengan rerata persentase asupan lemak sebelum penelitian $143.4 \% \pm 58.01 \%$ dan selama penelitian rerata persentase asupan $153.2 \% \pm 48.6 \%$. Pada sampel kontrol tingkat konsumsi lemak sebelum penelitian sebanyak $50 \%$ termasuk kategori lebih dengan rerata persentase asupan $125.6 \% \pm 66.02 \%$ dan selama penelitian sebanyak $40 \%$ termasuk kategori lebih dengan rerata persentase asupan $113.02 \% \pm 44.9 \%$. Sedangkan tingkat konsumsi karbohidrat sampel perlakuan sebelum penelitian sebanyak $70 \%$ termasuk kategori kurang dengan rerata persentase asupan $86.5 \% \pm 13.5 \%$ dan selama penelitian sebanyak $60 \%$ termasuk kategori kurang dengan rerata persentase asupan $89.2 \% \pm 21.7 \%$. Tingkat konsumsi karbohidrat sampel kontrol sebelum dan selama penelitian sebanyak $100 \%$ termasuk kategori kurang dengan rerata persentase asupan sebelum $69.4 \% \pm 16.6 \%$ dan selama penelitian rerata persentase asupan $73.5 \% \pm 8.7 \%$.

Rerata asupan serat pada kedua sampel seluruhnya (100\%) termasuk kategori kurang, dimana rerata asupan serat pada sampel perlakuan sebelum penelitian $38.9 \% \pm 18.5 \%$ dan selama penelitian $57.6 \% \pm 12.62 \%$, sedangkan rerata asupan serat pada sampel kontrol sebelum penelitian $27.4 \% \pm 11.2 \%$ dan selama penelitian $33.0 \% \pm 17.4 \%$.

Tabel 4. Rerata asupan serat selama intervensi

\begin{tabular}{llc}
\hline Asupan & Serat (gram) & $\%$ \\
\hline Asupan serat dari makanan lain & 7.8 gram & $31 \%$ \\
\hline Asupan serat dari puding & 6.6 gram & $26.40 \%$ \\
\hline Total & 14.35 gram & $57.60 \%$
\end{tabular}

Berdasarkan tabel 4. Menunjukkan bahwa total rerata asupan serat respon selama intervensi adalah 14.35 gram (57.6\%). Dari hasil tersebut dapat dilihat bahwa asupan serat sampel kurang dari yang dianjurkan yaitu 25 gram/hari.

\section{Rerata Kadar Glukosa Darah Puasa (GDP)}

\begin{tabular}{lccc}
\hline & Perlakuan & Kontrol & $p$ \\
\cline { 2 - 4 } \multicolumn{1}{c}{ Variabel } & Mean \pm SD & Mean \pm SD & $0.991^{*}$ \\
\hline sebelum $(\mathrm{mg} / \mathrm{dL})$ & $156.4 \pm 49.7$ & $156.7 \pm 68.05$ & $0.046^{*}$ \\
\hline sesudah $(\mathrm{mg} / \mathrm{dL})$ & $121.10 \pm 24.9$ & $205.8 \pm 122.7$ & $0.070^{* *}$ \\
\hline$\Delta$ kadar GDP & $35 \pm 10.5$ & $-49.1 \pm 137.2$ & 0.29 \\
\hline$p^{* * *}$ paired $t$-test & 0.01 & \\
$p^{*}$ indpenden $t$ - test & & \\
$p^{* *}$ mann-whitney & $\begin{array}{l}\text { Pemeriksaan glukosa darah puasa } \\
\text { glukosa darah puasa sebelum dan sesudah penelitian, serta selisih perubahan glukosa darah puasa pada kedua } \\
\text { sampel dapat dilihat pada tabel 5. }\end{array}$
\end{tabular}

Tabel 5. Rerata kadar Glukosa Darah Puasa (GDP) Sebelum dan Sesudah Penelitian

Rerata kadar gula darah puasa pada kelompok perlakuan sebelum penelitian diketahui sebesar $156.4 \pm 49.7 \mathrm{mg} / \mathrm{dL}$ dan pada kelompok kontrol sesudah penelitian adalah $156.7 \pm 68.05 \mathrm{mg} / \mathrm{dL}$. Berdasarkan hasil uji statistik tidak ditemukan adanya perbedaan kadar gula darah puasa pada kelompok kontrol dan perlakuan sebelum penelitian, sehingga dapat dikatakan kadar gula darah puasa kedua sampel adalah homogen.

Hasil uji paired t-test kadar gula darah puasa pada kelompok perlakuan menunjukkan adanya pernedaan kadar glukosa darah puasa sebelum dan sesudah penelitian dengan penurunan kadar gula darah puasa dari $156.4 \mathrm{mg} / \mathrm{dL}$ menjadi $121.10 \mathrm{mg} / \mathrm{dL}$ dengan rerata penuruan $35 \mathrm{mg} / \mathrm{dL}$, berdasarkan uji mann-whitney menunjukkan tidak ada 
perbedaan kadar gula darah puasa yang bermakna antara sampel perlakuan dan kontrol sesudah penelitian sehingga dapat disimpulkan bahwa pemberian puding susu buah naga merah tidak berpengaruh terhadap kadar kadar glukosa darah puasa pasien diabetes mellitus tipe 2 .

\section{PEMBAHASAN}

Karakteristik pada penelitian ini menunjukan sebagian besar sampel berumur 50-59 tahun. Faktor usia mempengaruhi penurunan pada semua sistem tubuh salah satunya menyebabkan resistensi insulin. Semakin meningkatnya umur seseorang maka semakin besar kejadian DM tipe dua (Brunner \& Suddarth, 2013 dalam Isnaini \& Ratnasari, 2018). Selain itu dengan bertambahnya umur seseorang maka kemampuan jaringan mengambil glukosa darah semakin menurun (Suiraoka, 2012 dalam Palimbunga, et al., 2017). Proses penuaan menjadi peyebab penyusutan sel-sel beta yang progresif sehingga sekresi insulin semakin berkurang dan kepekaan reseptor turut menurun yang kebanyakan timbul pada penderita di atas usia 40 tahun (Mahendra et al., 2008).

Responden pada penelitian ini sebagian besar adalah perempuan. Penyebab utama banyaknya perempuan terkena diabetes tipe 2 karena terjadinya penurunan hormon estrogen terutama saat masa menopause yaitu pada umur 48-54 tahun. Sindroma siklus bulanan (premenstrual syndrome), pasca-menopouse yang membuat distribusi lemak tubuh menjadi mudah terakumulasi akibat proses hormonal. Hormon estrogen dan progesteron memiliki kemampuan untuk meningkatkan respons insulin di dalam darah. Pada saat masa menopause terjadi, maka respon akan insulin menurun akibat hormon estrogen dan progesteron yang rendah. (Taylor, 2010 dalam Endriyanto, 2012). Sebagian besar sampel memiliki riwayat penyakit diabetes. Teori menyatakan bahwa seseorang memiliki peluang lebih besar untuk terserang diabetes mellitus jika salah satu atau kedua orang tuanya menderita penyakit tersebut, hal ini berkaitan dengan gen penyebab diabetes mellitus yang akan diwariskan (Mahendra et al., 2008) Selain itu sekitar $40 \%$ diabetes terbukti terlahir dari keluraga yang juga mengidap DM. Kembar identik merupakan penyandang DM dengan pravelensi 60-90\% (Arisman, 2013).

Sebagian besar responden mengkonsumsi obat antidiabetes. Pada pasien diabetes mellitus tipe 2 yang tidak mampu lagi mencapai kadar glukosa normal dengan pengaturan pola makan dan aktifitas fisik maka diperlukan pendekatan farmakologi dengan penggunaan obat oral antiabetes untuk mencapai kadar glukosa normal (Dipiro, 2005 dalam Lestari, 2013) Pengobatan farmakalogi juga bertujuan untuk membantu mencegah gangguan tekanan darah, dislipidemia, dan komplikasi vaskular (Kurniawan, 2010 dalam Wijaya et al., 2015).Terapi farmakologis diberikan bersama dengan pengaturan makan dan latihan jasmani (gaya hidup sehat). Berbagai jenis obat antidiabetes oral diantaranya sulfonilura dan Glinid sama-sama bekerja dalam meningkatkan sekresi insulin, Metformin dan Tiazolidindion (TZD) dengan meningkatkan sensivitas terhadap insulin, penghambat Alfa- Glukosidase dengan menghambat absorpsi glukosa di saluran pencernaan. penghambat DPP-IV (Dipeptidyl Peptidase- IV) dengan meningkatkan sekresi insulin dan menekan sekresi glukagon, penghambat SGLT-2 (Sodium Glucose Transporter 2) dengan menghambat penyerapan kembali glukosa di tubuli distal ginjal (Perkeni, 2015).

Pada penelitian ini sebagian besar termasuk akifitas ringan. Tujuan melakukan aktivitas fisik adalah untuk merangsang kembali sensitifitas dari sel terhadap insulin serta pengurangan lemak sentral dan perubahan jaringan otot (Kriska, 2010 dalam Azitha et al., 2018).Meningkatnya sensitifitas insulin menyebabkan glukosa di dalam darah dapat diubah menjadi energi melalui proses metabolisme sehingga kadar glukosa dalam darah dapat dikendalikan, selain itu aktifitas fisik mencegah kegemukan, berperan dalam mencegah komplikasi, gangguan lipid dan peningkatan tekanan darah (Ilyas et al., 2011 dalam Nurayati \& Adriani, 2017).

Responden pada penelitian ini sebagian besar mengalami obesitas. Seseorang yang kelebihan berat badan lebih berisiko untuk terkena berbagai macam penyakit seperti diabetes, penyakit jantung, stroke, hipertensi dan osteoarthritis (Hartono, 2004 dalam Septyaningrum \& Martini, 2014). Kegemukan akan menyebabkan adanya resistensi insulin, sel-sel lemak pada pasien obesitas akan mengeluarkan lebih banyak lemak asam (lipid acid) yang menyebabkan menurunnya fungsi sel beta di pankreas dan menurunnya sensitivitas jaringan atau sel terhadap insulin (Mahendra et al., 2008). Pada kondisi obesitas berkorelasi dengan indeks massa tubuh (IMT) dan resistensi insulin (Lina et al., 2011 dalam Karundeng et al., 2014). Obesitas merupakan suatu keadaan dengan akumulasi lemak yang tidak normal atau berlebihan di jaringan adiposa (Sugondo, 2010 dalam karundeng et al., 2014). Adiposa akan mensekresi hormon adiponektin yang berfungsi sebagai sensitisasi insulin dan sifat antiperadangan (Codario, 2011 
karundeng et al., 2014). Namun, adiponektin menurun pada individu yang mengalami obesitas dan akan meningkat jika terjadi penurunan berat badan (Illouz \& Sterodimas, 2011 dalam Pondagitan et al., 2014).

Pada penderita diabetes mellitus, efek perbaikan sensivitas insulin diperoleh melalui kerja adiponektin dalam menurunkan produksi glukosa hati, meningkatkan pengambilan glukosa dan menurukan kadar asam lemak bebas (Snijder et al., 2006 dalam karundeng et al., 2014). Selain itu hormon adiponektin mendorong oksidasi asam lemak oleh otot, meningkatkan sensitivitas terhadap insulin, menurunkan berat badan dengan meningkatkan pengeluaran energi dan memiliki efek antiinflamasi (Sherwood, 2013 dalam Luntungan et al., 2014).

\section{Asupan Zat Gizi}

Pada asupan energi yang melebihi kebutuhan tubuh menyebabkan lebih banyak glukosa yang ada dalam tubuh sehingga jaringan tubuh tidak mampu untuk menyimpan dan menggunakan glukosa, akibatnya kadar glukosa darah akan naik dan akan menyebabkan hiperglikemia (Hartono, 2002 dalam Muliani, 2013), namun sebaliknya asupan energi kurang dapat menyebabkan hipoglikemia yang berakibat pada penurunan kesadaran pada pasien diabetes mellitus tipe II (Perkeni, 2015). Selain itu kadar glukosa darah tidak hanya di pengaruhi oleh asupan energi tetapi juga karena kurangnya aktifitas fisik, berat badan berlebih dan menurunya fungsi-fungsi organ tubuh pada lansia (Simanullang et al., 2011 dalam Puspitasari, 2014). Pada puding susu buah naga ditambahkan susu skim. Serangkaian studi metabolik dan epideminologi menunjukkan asupan tinggi produk susu dikaitkan dengan penurunan diabetes tipe 2 yang signifikan terutama pada susu rendah lemak, susu skim, keju dan yoghurt (Liu et al., 2006).

Penelitian yang dilakukan oleh Liu et al., (2006) selama 10 tahun menunjukkan dengan mengkonsumsi susu skim lebih dari 2 porsi perhari dapat menurunkan resiko diabetes tipe 2 pada wanita paruh baya atau lanjut usia. Hal ini berkaitan dengan Kemampuan susu untuk meningkatkan sekresi asam amino insulinotropik dan hormon inkretin yang dapat membantu mengurangi insidensi diabetes tipe 2. Penelitian Linn et al., 2000 dalam (Leoni, 2012) menunjukkan adanya hubungan yang signifikan antara asupan protein dengan sekresi insulin, semakin tinggi asupan protein maka semakin tinggi juga sekresi insulin sehingga glukosa didalam darah tetap terjaga. Penelitian lain oleh Martini dan Wood (2009) juga memperoleh hasil yang sama yaitu konsumsi susu rendah lemak 3 porsi perhari memiliki efek menguntungkan pada pencegahan penyakit kronis (hipertensi dan diabetes). Meta analisis studi kohort oleh (Tong et al., 2011) konsumsi susu rendah lemak secara signifikan menurunkan resiko DM tipe 2 sebesar $18 \%$ dengan konsumsi 1 porsi susu perhari.

Lemak yang diperoleh sebagian besar dari makanan disimpan dalam bentuk triasilgliserol dalam jaringan adiposa. Peningkatan triasigliserol akan menyebabkan sel adiposit berusaha mempertahankan keseimbangan energi dengan melepaskan sitokin-sitokin proinflamasi yang disebut adiponektin (Xu, et al., 2007 dalam Luntungan et al., 2014). Adiponektin merupakan suatu hormon protein yang dihasilkan oleh jaringan adiposit yang merupakan regulator penting metabolisme lipid dan glukosa. Fungsi adiponektin diantaranya adalah mendorong oksidasi asam lemak oleh otot, meningkatkan sensitivitas terhadap insulin, menurunkan berat badan dengan meningkatkan pengeluaran energi, dan memiliki efek antiinflamasi (Sherwood, 2013 dalam Luntungan et al., 2014), namun asupan lemak yang tinggi menjadi salah satu penyebab tidak langsung terjadinya penurunan kadar adiponektin dalam jaringan adiposa.Pada penderita DM tipe 2 mengalami resistensi insulin yang berhubungan dengan sindrom metabolik yang diasosiasikan dengan abnormalitas serta peningkatan metabolisme asam lemak. Peningkatan jumlah asam lemak tidak hanya meningkatkan resistensi insulin, tetapi juga menaikkan tekanan darah, menurunkan tingkat HDL serta meningkatkan konsentrasi trigliserida (Codario, 2011 Luntungan et al., 2014).

Penelitian ini sejalan dengan penelitian Leoni (2012) dimana asupan karbohidrat sampel penelitian sebanyak $91.6 \%$ termasuk kategori kurang. Penelitian ini juga sejalan dengan penelitian Purba et al., (2015) dimana asupan karbohidrat sampel penelitian sebanyak 93.3\% termasuk kategori kurang. Asupan karbohidrat termasuk kategori kurang hal ini bisa jadi karena sampel sudah mendapatkan informasi di posbindu terkait pembatasan asupan karbohidrat sederhana, namun penyebab terjadinya kegemukan atau obesitas tidak hanya disebabkan oleh kelebihan asupan karbohidrat saja tetapi juga karena kelebihan asupan lemak serta aktivitas fisik yang kurang dapat menyebabkan kelebihan berat badan karena terjadi penumpukan lemak di dalam tubuh (Bintanah \& Muryati, 2010 dalam Leoni, 2012).

Penelitian ini sejalan dengan penelitian oleh Rahmawati (2010) dengan rerata asupan serat penyandang diabetes yaitu 9.1 gram/hari. Penelitian oleh Bintanah \& Handarsari (2012) menunjukkan rerata asupan serat penyandang diabetes yaitu 7.9 gram/hari. Penelitian oleh Wiardani et al., (2007) rerata asupan serat yaitu 8.7 gram/ hari sementara anjuran konsumsi serat menurut Perkeni (2015) sebesar 20-35 gram/hari. 
Makanan tinggi serat sangat dianjurkan untuk penderita diabetes terutama serat larut air. Serat jenis ini dapat memperlambat penyerapan glukosa sesudah makan, juga mempengaruhi penyerapan lemak dari saluran pencernaan (Dalimartha \& Adrian, 2011). Proses penyerapan glukosa dan lemak oleh serat dengan cara meningkatkan kekentalan feses yang secara tidak langsung menurunkan kecepatan difusi sehingga kadar glukosa darah, profil lipid dan kolesterol menurun (Sulistyani, 2012 dalam Hidayati, 2017).Mekanisme serat pangan dalam menurunkan kadar gula darah pasien diabetes adalah dengan menurunkan efisiensi penyerapan karbohidrat sehingga menyebabkan turunnya respon insulin dan mengakibatkan kerja pankreas semakin ringan sehingga dapat memperbaiki fungsi pankreas dalam menghasilkan insulin (Astawan \& Kasih, 2008).

\section{Pengaruh Pemberian Puding Susu Buah Naga Merah (Hylocereus polyrhizus)}

Buah naga mengandung serat larut air yang digunakan sebagai terapi hipoglikemia (Widyastuti \& Noer, 2015). Serat jenis ini dapat memperlambat penyerapan glukosa sesudah makan, juga mempengaruhi penyerapan lemak dari saluran pencernaan (Dalimartha \& Adrian, 2011).Selain serat, buah naga mengandung antioksidan yang dapat mengikat radikal bebas sehingga dapat mengurangi resistensi insulin dan dapat menurunkan Reaktive Oxygen Species (Ruhe, 2009 dalam Hidayati, 2017). Antioksidan pada buah naga diantaranya $\beta$-karoten 1,4 $\mu \mathrm{g}$, likopen 3,4 $\mu \mathrm{g}$, dan vitamin E 0,26 $\mu \mathrm{g}$ (Charoensiri, 2009 dalam Nurhayati et al., 2015).Kandungan senyawa likopen yang tinggi mempengaruhi resistensi hormon insulin sehingga toleransi tubuh terhadap glukosa meningkat (Astawan \& Kasih, 2008). Pada pembuatan puding juga di tambahkan susu skim yang mengandung magnesium, kalsium, laktosa dan protein susu yang dapat meningkatkan rasa kenyang dan mengurangi resiko kelebihan berat badan (Liu et al., 2006).

Hasil penelitian rerata kadar gula darah puasa pada kelompok perlakuan sebelum penelitian diketahui sebesar $156.4 \pm 49.7 \mathrm{mg} / \mathrm{dL}$ dan pada kelompok kontrol sesudah penelitian adalah $156.7 \pm 68.05 \mathrm{mg} / \mathrm{dL}$. Berdasarkan hasil uji statistik tidak ditemukan adanya perbedaan kadar gula darah puasa pada kelompok kontrol dan perlakuan sebelum penelitian, sehingga dapat dikatakan kadar gula darah puasa kedua sampel adalah homogen.Hasil uji paired t-test kadar gula darah puasa pada kelompok perlakuan menunjukkan adanya pernedaan kadar glukosa darah puasa sebelum dan sesudah penelitian dengan penurunan kadar gula darah puasa dari $156.4 \mathrm{mg} / \mathrm{dL}$ menjadi $121.10 \mathrm{mg} / \mathrm{dL}$ dengan rerata penuruan $35 \mathrm{mg} / \mathrm{dL}$, berdasarkan uji mann-whitney menunjukkan tidak ada perbedaan kadar gula darah puasa yang bermakna antara sampel perlakuan dan kontrol sesudah penelitian sehingga dapat disimpulkan bahwa pemberian puding susu buah naga merah tidak berpengaruh terhadap kadar kadar glukosa darah puasa pasien diabetes mellitus tipe 2 .

Hasil penelitian ini berbeda dengan penelitian Hidayati (2017) yang menunjukkan adanya pengaruh pemberian buah naga merah 200 gram terhadap kadar glukosa darah puasa (GDP) pasien diabetes mellitus tipe 2 sebesar 19,1 $\mathrm{mg} / \mathrm{dL}$. Penelitian oleh Wiardani et al., (2014) pemberian jus buah naga merah $200 \mathrm{~g}$ membantu menurunkan kadar glukosa darah 2 Jam Post Prondrial (2 JPP) sebesar 79,1 mg/dL.

Beberapa penyebab perbedaan hasil penelitian ini dengan penelitian sebelumnya karena adanya perbedaan karakteristik pada sampel perlakuan dan sampel kontrol diantaranya perbedaan karakteristik umur, jenis kelamin, persentase asupan protein dan karbohidrat sebelum penelitian. Selain itu pada rerata konsumsi serat baik dari bahan intervensi dan makanan lain hanya sebesar 14.4 gram termasuk kategori kurang (57.6\%), sehingga belum mampu memenuhi kebutuhan serat sampel. Faktor lainnya adalah aktifitas fisik sampel sebagian besar $(75 \%)$ termasuk kategori aktifitas ringan. Aktifitas ringan menyebabkan resistensi insulin pada diabetes mellitus tipe, oleh sebab itu tujuan melakukan aktivitas fisik adalah untuk merangsang kembali sensitifitas dari sel terhadap insulin serta pengurangan lemak sentral dan perubahan jaringan otot (Kriska, 2010 dalam Azitha et al., 2018). Penatalaksanaan diabetes mellitus perlu di tambahkan dengan edukasi terkait diet diabetes mellitus, diet serat tinggi, aktifitas fisik dan farmakologi.

\section{KESIMPULAN}

Karakteristik sampel penelitian:Total sampel penelitian yaitu 20 orang, dimana sebanyak $85 \%$ sampel berumur diatas 50 tahun, berjenis kelamin perempuan sebanyak 65\% sampel, memiliki riwayat penyakit keluarga sebanyak $60 \%$ sampel, mengkonsumsi obat antidiabetes sebanyak 70\% sampel, aktifitas fisik sebanyak $75 \%$ kategori aktifitas ringan, status gizi sebanyak $65 \%$ sampel kategori beresiko dan obesitas. Tingkat konsumsi pada sampel perlakuan untuk energi kategori baik, protein dan lemak kategori lebih sedangkan karbohidrat kategori kurang. Pada sampel 
kontrol untuk energi, protein dan karbohidrat kategori kurang sedangkan lemak kategori lebih untuk supan serat pada kedua kelompok kategori kurang

Rerata kadar glukosa darah sebelum penelitian pada kelompok perlakuan $156.4 \pm 49.7 \mathrm{mg} / \mathrm{dL}$ dan sesudah penelitan $121.10 \pm 24.9 \mathrm{mg} / \mathrm{dL}$ dengan penurunan $35 \mathrm{mg} / \mathrm{dL}$, sedangkan rerata kadar glukosa darah sebelum penelitian pada kelompok kontrol 156.7 $\pm 68.05 \mathrm{mg} / \mathrm{dL}$ dan sesudah penelitian $205.8 \pm 122.7 \mathrm{mg} / \mathrm{dL}$ dengan penurunanan -49.1 $\mathrm{mg} / \mathrm{dL}$.

Hasil uji statistik menunjukan tidak ada pengaruh pemberian puding susu buah naga merah (hylocereus polyrhizus) terhadap glukosa darah puasa pasien diabetes mellitus tipe 2 dikelurahan abian tubuh baru.

\section{SARAN}

Anjuran serat untuk pasien diabetes adalah 20-35 gram/hari sedangkan sumbangan serat dari pudding susu buah naga merah hanya $26.6 \%$ dari kebutuhan sehingga untuk penelitian selanjutnya perlu ditambahkan dengan konseling gizi untuk meningkatkan konsumsi serat sampel dari makanan lain selain bahan intervensi dan peningkatan aktifitas fisik dengan jalan sehat setiap pagi atau sore hari.

Pada penelitian ini tidak semua pasien mengkonsumsi obat antidiabetes sehingga pada penelitian selanjutnya perlu ditetapkan kriteria eksklusi pada sampel penelitian seluruhnya mengkonsumsi obat antidiabetes.

\section{DAFTAR PUSTAKA}

Adnan, M., Mulyati, T. and Isworo, J. T. (2013) 'Hubungan Indeks Massa Tubuh ( IMT ) dengan Kadar Gula Darah Penderita Diabetes Mellitus ～( DM ) Tipe 2 Rawat Jalan Di RS Tugurejo Semarang', 2(April), pp. 18-25.

Almatsier, S. (2004) Penuntun Diet. Jakarta: PT Gramedia Pustaka Utama.

Arisman (2013) Obesitas, Diabetes mellitus, dan Displidemia: Konsep, Teori dan Penanganan aplikatif seri buku ajar ilmu gizi. Jakarta.

Astawan, M. and Kasih, A. L. (2008) Khasiat Warna-Warni Makanan. Jakarta: PT Gramedia Pustaka Utama.

Azitha, M., Aprilia, D. and Ilhami, Y. R. (2018) 'Hubungan Aktivitas Fisik dengan Kadar Glukosa Darah Puasa pada Pasien Diabetes Melitus yang Datang ke Poli Klinik Penyakit Dalam Rumah Sakit M . Djamil Padang', 7(3), pp. 400-404.

Bintanah, S. and Handarsari, E. (2012) ‘Asupan Serat Dengan Kadar Gula Darah, Kadar Kolesterol Total Dan Status Gizi Pada Pasien Diabetus Mellitus Tipe 2 Di Rumah Sakit Roemani Semarang’, 001.

Dalimartha, S. and Adrian, F. (2011) Khasiat Buah dan Sayur. Jakarta: Penebar Swadaya.

Faridah, A. et al. (2008) Pastiseri Jilid 3. Jakarta: Direktorat Pembinaan Sekolah Menengah Kejuruan.

Firdayati, F. (2015) 'Pengaruh Pemberian Agar-Agar Buah Naga Merah (Hylocereus Polyrhizus) Terhadap Kadar Glukosa Darah Pasien Diabetes Mellitus Tipe Ii Di Wilayah Kerja Puskesmas Salido Kabupaten Pesisir Selatan Tahun 2015.' Padang: Politeknik Kesehatan Kemenkes Padang.

Hidayati, A. R. (2017) 'Pengaruh buah naga terhadap kadar glukosa darah pasien diabetes melitus tipe II di puskesmas temon 1 kulon progo yogyakarta', p. 11. Available at: http://digilib.Unisayogya.Ac.Id/2505/1/Naskah Publikasi_Ana Roiffatul Hidayati.Pdf.

Isnaini, N. and Ratnasari (2018) 'Faktor risiko mempengaruhi kejadian Diabetes mellitus tipe dua Risk factors was affects of diabetes mellitus type 2', 14(1), pp. 59-68

Karundeng, G., Kapantow, N. H. and Joseph, W. B. S. (2014) 'Hubungan antara Indeks Massa Tubuh dengan Kadar Adiponektin Pada Penderita Diabetes Melitus Tipe 2 di Kota Manado.' Manado: Universitas Sam Ratulangi. 
Leoni, A. P. (2012) 'Hubungan Umur, Asupan Protein, dan Faktor lainnya dengan Kadar Gula Darah Puasa pada Pegawai SATLANTAS dan SUMDA di POLRESTA Depok.' Jakarta: Universitas Indonesia.

Lestari, W. P. (2013) 'Gambaran Efektivitas Penggunaan Obat Antidiabetik Tunggal dan Kombinasi Dalam Mengendalikan Gula Darah Pada Pasien Diabetes Mellitus Tipe II di Rumah Sakit Umum Pusat (RSUP) Fatmawati Tahun 2012.' Jakarta: UIN Syarif Hidayatullah Jakarta

Liu, S. et al. (2006) 'A prospective study of dairy intake and the risk of type 2 diabetes in women', Diabetes Care, 29(7), pp. 1579-1584. doi: 10.2337/dc06-0256.

Luntungan, A. H., Kapantow, N. H. and Malonda, N. S. H. (2014) 'Hubungan antara Asupan Lemak dengan Kadar Adiponektin Penderita Diabetes Melitus Tipe 2 di Kota Manado.’ Manado: Universitas Sam Ratulangi, pp. 17.

Mahendra et al. (2008) Care your self diabetes mellitus. Jakarta: Penebar Plus.

Martini, L. A. and Wood, R. J. (2009) 'Milk intake and the risk of type 2 diabetes mellitus, hypertension and prostate cancer.', Arquivos brasileiros de endocrinologia e metabologia, 53(5), pp. 688-694.

Muliani, U. (2013) 'Asupan zat-zat Gizi dan Kadar Gula Darah Penderita DM-Tipe2 Di Poliklinik Penyakit Dalam Rsud Dr. H. Abdul Moeloek Provinsi Lampung', Jurnal Kesehatan, Volume IV, Nomor 2,Oktober 2013, hlm 325-332, (4), pp. 325-332.

Nurayati, L. and Adriani, M. (2017) 'Hubungan Aktifitas Fisik dengan Kadar Gula Darah Puasa Penderita Diabetes Melitus Tipe 2 Association Between Physical Activity and Fasting Blood Glucose Among Type 2 Diabetes Mellitus patients', pp. 80-87. doi: 10.20473/amnt.v1.i2.2017.80-87.

Palimbunga, T. M., Ratag, B. T. And Kaunang, W. P. J. (2017) 'Faktor-Faktor Yang Berhubungan Dengan Kejadian Diabetes Melitus Tipe 2 Di Rsu Gmim Pancaran Kasih Manado’, Pp. 1-11.

Perkeni (2015) 'Pengolahan dan Pencegahan Diabetes Melitus Tipe 2 Di Indonesia 2015.' Jakarta: PB. PERKENI. doi: 10.1017/CBO9781107415324.004

Pondagitan, A., Kapantow, N. H. and Punuh, M. I. (2014) 'Hubungan antara Rasio Lingkar Pinggang Panggul (RLPP ) dengan Kadar Adiponektin Penderita Diabetes Melitus Tipe 2 di Kota Manado.' Manado: Universitas Sam Ratulangi

Purba, R. B. and Monolimay, N. R. M. S. (2015) 'Asupan Karbohidrat dan Lemak Pada Diabetesi Tipe II yang Rawat Jalan di Puskesmas Tombatu’, 362GIZIDO Volume 7 No. 2 November 2015, 7(2), pp. 362-367.

Puspitasari, R. W. (2014) 'Hubungan Asupan Energi, Lemak, Protein dan Karbohidrat dengan Kadar Gula Darah Pada Lansia Obesitas di Desa Blulukan Kecamatan Colomadu, Karanganyar, Jawa Tengah.' Surakarta: Universitas Muhammadiyah Surakarta.

Rahmawati, E. (2010) 'Hubungan Antara Konsumsi Karbohidrat Dan Serat Dengan Kadar Glukosa Darah (Studi Pada Penderita Diabetes Mellitus Tipe 2 Rawat Jalan Di Rsd Kalisat Kabupaten Jember)', Skripsi.

Riskesdas (2018) 'Hasil Utama Riskesdas Tentang Prevalensi Diabetes Mellitus di Indonesia 2018', Hasil Utama Riskesdas Tentang Prevalensi Diabetes Melitus di Indonesia 2018, p. 8. doi: 1 Desember 2013.

Salindeho, A., Mulyadi and Rottie, J. (2016) 'Pengaruh Senam Diabetes Melitus Terhadap Kadar Gula Darah Penderita Diabetes Melitus Tipe 2 Di Sanggar Senam Persadia Kabupaten Gorontalo.' Gorontalo: ejournal Keperawatan (e-Kp) Volume 4.

Septyaningrum, N. and Martini, S. (2014) 'Lingkar Perut Mempunyai Hubungan Paling Kuat dengan Kadar Gula Darah.' Surabaya: Jurnal Berkala Epideminologi. 
Tong, X. et al. (2011) 'Dairy consumption and risk of type 2 diabetes mellitus : a meta-analysis of cohort studies', dairy products; meta-analysis; type 2 diabetes mellitus: a meta-analisisofcohort studies. European Journal Of Clinical Nutrition, pp. 1027-1031. doi: 10.1038/ejcn.2011.62.

Wiardani, N. K., Hadi, H. and Huriyati, E. (2007) 'Pola makan dan obesitas sebagai faktor risiko diabetes mellitus tipe 2 di Rumah Sakit Sanglah Denpasar.’ Jurnal Gizi Klinik Indonesia.

Wiardani, N. K., Moviana, Y. and Puryana, S. (2014) 'Jus Buah Naga Merah Menurunkan Kadar Glukosa Darah Penderita DMT2 Ni Komang Wiardani 1 , Yenny Moviana 2 , I G.P. Sudita Puryana 3', Politeknik Kesehatan Denpasar, (Dm), pp. 59-66.

Widyastuti, A. N. and Noer, E. R. (2015) 'Pengaruh pemberian jus buah naga merah (Hylocereus polyrhizus) terhadap kadar glukosa darah puasa pria prediabetes', Journal of Nutrition College, 4(2), pp. 526-569. Available at: http://ejournal-s1.undip.ac.id/index.php/jnc.

Wijaya, I. N. et al. (2015) 'Profil Penggunaan Obat Pada Pasien Diabetes Melitus di Puskesmas Wilayah Surabaya Timur', 2(1), pp. 23-28. 
ISSN: 2656-2456 (Online)

ISSN: 2356-4075 (Print) 